\title{
AMINO ACID EXCRETION IN PRIMARY HYPERURICAEMIA*
}

\author{
BY \\ D. KAPLAN, H. DIAMOND, S. L. WALLACE, AND D. HALBERSTAM \\ From the Departments of Medicine, State University of New York Downstate Medical Center, \\ and the Jewish Hospital of Brooklyn, Brooklyn, New York
}

The demonstration that patients with primary hyperuricaemia are also hyperaminoacidaemic (Kaplan, Bernstein, Wallace, and Halberstam, 1965) has suggested the possibility that the presumptive renal tubular defect in the handling of uric acid by many such patients (Nugent and Tyler, 1959; Seegmiller, Grayzel, Howell, and Plato, 1962) may be only one manifestation of a more generalized defect in renal tubular cell transport that involves substances other than uric acid. For glycine, at least, this has been demonstrated; the renal clearance of endogenous glycine was decreased in subjects with primary hyperuricaemia compared with normouricaemic individuals. Furthermore, after either an oral or an intravenous glycine load, hyperuricaemic subjects failed to increase their renal clearance of glycine as much as did the normal subjects (Kaplan, Wallace, and Halberstam, 1966).

The present report records observations on 26 normouricaemic individuals and 25 subjects with primary hyperuricaemia and normal glomerular filtration rates in whom serum amino acid levels and renal clearances of twelve amino acids were measured. Responses to oral loads of three amino acids and the effects of RNA feeding on these parameters have also been investigated.

\section{Material and Methods}

51 men between the ages of 21 and 67 years were studied; 26 were normouricaemic, and 25 had primary hyperuricaemia (serum uric acid greater than $7 \mathrm{mg}$. per cent.), of whom all but two had a history of gouty arthritis, though none were tophaceous. None of the subjects was acutely ill at the time of the study. None had taken

*This work was supported by USPHS grants AM-05671, T1-AM08106 and a grant from the NY Chapter of the Arthritis Foundation. any drugs for at least 3 days before the study, except for three gouty subjects who were maintained on their prophylactic colchicine up to the day of the investigation. No subject had known hepatic or gastrointestinal disease. All had glomerular filtration rates higher than $80 \mathrm{ml}$./ min. and normal urinary sediments. The hyperuricaemic subjects were ambulatory clinic patients or hospitalized patients who were convalescent from either an attack of gouty arthritis or some other disease. The normouricaemic subjects consisted of either normal hospital personnel or hospitalized patients in the convalescent phase of their disease.

All observations were made after an overnight fast. To rule out the possibility that serum levels of amino acids might be related to the type of diet before the study, six patients were studied after an ad lib diet and again after 2 days on a $40 \mathrm{~g}$. protein diet. No differences in serum levels were observed.

An estimation of glomerular filtration rates was made on each subject by measurement of either inulin clearances or endogenous creatinine clearance. Uric acid and amino acid clearances were measured simultaneously. Urine and serum samples for amino acid analyses were stored at $-70^{\circ} \mathrm{C}$. before analysis. Standard techniques were used for the measurement of creatinine (Bonsnes and Taussky, 1945), inulin (Harrison, 1942), uric acid (Praetorius, 1949), and amino acids (Kaplan and others, 1965; Dickinson, Rosenblum, and Hamilton, 1965).

Fourteen normouricaemic and fourteen hyperuricaemic individuals were subjected to oral amino acid tolerance tests. After the overnight fast, a 2-hour urine specimen was collected and blood was drawn so that uric acid, creatinine, and amino acid clearances could be determined. At this point, each subject ingested either $5 \mathrm{~g}$. glycine alone (6 in each group), $5 \mathrm{~g}$. each of glycine, valine, and arginine ( 7 in each group), 5 g. each of glycine and arginine (1 normouricaemic subject), or $5 \mathrm{~g}$. each of glycine and valine (1 hyperuricaemic subject). Blood was collected at 15, 30, 45, 60, 90, and 120 minutes after the dose of amino acid and another urine specimen was collected 2 hours after the amino acid loading. 


\section{Results}

Pertinent data on these 51 subjects is shown in Tables I and II.

The mean age of the patients with hyperuricaemia was $42 \pm 11$ years, and that of the normal group $37 \pm 11$ years $(0 \cdot 10>P>0 \cdot 05)$.
The mean glomerular filtration rate (GFR) of the hyperuricaemic group was $117 \pm 24 \mathrm{ml}$. $/ \mathrm{min}$., and that of the normal group $130 \pm 37 \mathrm{ml} . / \mathrm{min} .(0 \cdot 2>$ $P>0 \cdot 1$ ). One "hyperuricaemic" subject (No. 36) actually had a serum uric acid of $4.5 \mathrm{mg}$. per cent. He was included here because he had a history of gouty arthritis (several episodes of monarticular

TABLE I

DATA ON 26 NORMOURICAEMIC SUBJECTS

\begin{tabular}{|c|c|c|c|c|c|c|}
\hline $\begin{array}{c}\text { Patient } \\
\text { No. }\end{array}$ & $\begin{array}{c}\text { Age } \\
\text { (yrs) }\end{array}$ & Diagnosis & $\begin{array}{c}\text { GFR* } \\
\text { (ml./min.) }\end{array}$ & $\begin{array}{c}\text { Serum } \\
\text { Uric Acid } \\
\text { (mg. per cent.) }\end{array}$ & $\begin{array}{l}\text { Total Serum } \dagger \\
\text { Amino Acids } \\
(\mu \mathrm{M} / \mathrm{ml} .)\end{array}$ & $\begin{array}{c}\text { Uric Acid/ } \\
\text { Creatinine } \\
\text { Clearance } \times 100\end{array}$ \\
\hline $\begin{array}{r}1 \\
2 \\
3 \\
4 \\
5 \\
6 \\
7 \\
8 \\
9 \\
10 \\
11 \\
12 \\
13 \\
14 \\
15 \\
16 \\
17 \\
18 \\
19 \\
20 \\
21 \\
22 \\
23 \\
24 \\
25 \\
26\end{array}$ & $\begin{array}{l}36 \\
52 \\
22 \\
35 \\
52 \\
24 \\
29 \\
28 \\
56 \\
45 \\
29 \\
43 \\
50 \\
30 \\
35 \\
34 \\
34 \\
44 \\
47 \\
58 \\
38 \\
45 \\
21 \\
25 \\
27 \\
28\end{array}$ & $\begin{array}{l}\text { Normal } \\
\text { Pneumonia } \\
\text { Normal } \\
\text { Normal } \\
\text { Myocardial infarction } \\
\text { Normal } \\
\text { Normal } \\
\text { Normal } \\
\text { Pneumonia } \\
\text { Coronary artery disease } \\
\text { Normal } \\
\text { Normal } \\
\text { Coronary artery disease } \\
\text { Pneumonia } \\
\text { Pneumonia } \\
\text { Pneumonia } \\
\text { Normal } \\
\text { Pneumonia } \\
\text { Pneumonia } \\
\text { Coronary artery disease } \\
\text { Normal } \\
\text { Normal } \\
\text { Normal } \\
\text { Normal } \\
\text { Normal } \\
\text { Normal }\end{array}$ & $\begin{array}{l}125 \\
155 \\
115 \\
182 \\
81 \\
141 \\
82 \\
186 \\
121 \\
154 \\
138 \\
158^{*} \\
141^{*} \\
104^{*} \\
108^{*} \\
122^{*} \\
121^{*} \\
147^{*} \\
161^{*} \\
112 \\
119^{*} \\
140^{*} \\
132^{*} \\
104 \\
108 \\
116\end{array}$ & $\begin{array}{l}5 \cdot 3 \\
5 \cdot 9 \\
5 \cdot 8 \\
5 \cdot 4 \\
6 \cdot 0 \\
6 \cdot 4 \\
6 \cdot 2 \\
4 \cdot 1 \\
2 \cdot 9 \\
5 \cdot 4 \\
4 \cdot 7 \\
4 \cdot 8 \\
3 \cdot 7 \\
3 \cdot 0 \\
6 \cdot 4 \\
4 \cdot 1 \\
5 \cdot 5 \\
4 \cdot 4 \\
5 \cdot 1 \\
4 \cdot 9 \\
5 \cdot 4 \\
5 \cdot 6 \\
4 \cdot 0 \\
5 \cdot 8 \\
4 \cdot 4 \\
6 \cdot 0\end{array}$ & $\begin{array}{l}2 \cdot 354 \\
2 \cdot 170 \\
2 \cdot 552 \\
2 \cdot 128 \\
2 \cdot 707 \\
2 \cdot 743 \\
2 \cdot 296 \\
2 \cdot 143 \\
2 \cdot 442 \\
2 \cdot 209 \\
2 \cdot 431 \\
1 \cdot 868 \\
2 \cdot 098 \\
2 \cdot 371 \\
2 \cdot 414 \\
1 \cdot 596 \\
1 \cdot 717 \\
1 \cdot 771 \\
1 \cdot 553 \\
2 \cdot 322 \\
2 \cdot 181 \\
1 \cdot 866 \\
2 \cdot 025 \\
2 \cdot 018 \\
2 \cdot 262 \\
2 \cdot 412\end{array}$ & $\begin{array}{r}7 \cdot 5 \\
4 \cdot 1 \\
3 \cdot 0 \\
5 \cdot 7 \\
4 \cdot 5 \\
4 \cdot 1 \\
7 \cdot 1 \\
8 \cdot 0 \\
6 \cdot 7 \\
3 \cdot 9 \\
7 \cdot 1 \\
8 \cdot 3 \\
6 \cdot 1 \\
9 \cdot 7 \\
5 \cdot 9 \\
7 \cdot 6 \\
6 \cdot 8 \\
7 \cdot 3 \\
9 \cdot 6 \\
5 \cdot 8 \\
7 \cdot 2 \\
6 \cdot 0 \\
11 \cdot 7 \\
3 \cdot 6 \\
6 \cdot 3 \\
7 \cdot 1\end{array}$ \\
\hline
\end{tabular}

* Glomerular filtration rate (GFR) is measured either as inulin clearance ${ }^{*}$ ) or 2-hour endogenous creatinine clearance.

†Total serum amino acids include aspartic acid, threonine, serine, glutamic acid, glycine, alanine, valine, isoleucine, leucine, tyrosine, phenylalanine, ornithine, lysine and histidine.

TABLE II

DATA ON 25 HYPERURICAEMIC SUBJECTS

\begin{tabular}{|c|c|c|c|c|c|c|}
\hline $\begin{array}{l}\text { Patient } \\
\text { No. }\end{array}$ & $\begin{array}{l}\text { Age } \\
\text { (yrs) }\end{array}$ & Diagnosis & $\begin{array}{c}\text { GFR } \\
\text { (ml./min.) }\end{array}$ & $\begin{array}{c}\text { Serum } \\
\text { Uric Acid } \\
\text { (mg. per cent.) }\end{array}$ & $\begin{array}{c}\text { Total Serum } \\
\text { Amino Acids } \\
(\mu \mathrm{M} / \mathrm{ml} .)\end{array}$ & $\begin{array}{c}\text { Uric Acid/ } \\
\text { Creatinine } \\
\text { Clearance } \times 100\end{array}$ \\
\hline $\begin{array}{l}27 \\
28 \\
29 \\
30 \\
31 \\
32 \\
33 \\
34 \\
35 \\
36 \\
37 \\
38 \\
39 \\
40 \\
41 \\
42 \\
43 \\
44 \\
45 \\
46 \\
47 \\
48 \\
49 \\
50 \\
51\end{array}$ & $\begin{array}{l}45 \\
42 \\
28 \\
23 \\
47 \\
38 \\
54 \\
35 \\
38 \\
48 \\
52 \\
25 \\
35 \\
57 \\
67 \\
56 \\
34 \\
44 \\
43 \\
33 \\
44 \\
53 \\
34 \\
42 \\
44\end{array}$ & $\begin{array}{l}\text { Gout } \\
\text { Gout } \\
\text { Gout } \\
\text { Hyperuricaemia } \\
\text { Gout } \\
\text { Gout } \\
\text { Gout } \\
\text { Gout } \\
\text { Gout } \\
\text { Gout } \\
\text { Gout } \\
\text { Gout } \\
\text { Gout } \\
\text { Gout } \\
\text { Gout } \\
\text { Gout } \\
\text { Gout } \\
\text { Gout } \\
\text { Gout } \\
\text { Gout } \\
\text { Gout } \\
\text { Gout } \\
\text { Gout } \\
\text { Gout } \\
\text { Hyperuricaemia }\end{array}$ & $\begin{array}{r}172 \\
99 \\
89 \\
125 \\
102 \\
86 \\
83 \\
112 \\
98 \\
142 \\
110 \\
107 \\
123 \\
97 \\
124 \\
88 \\
119 \\
173 \\
98 \\
141 \\
110 \\
141 \\
135 \\
120 \\
120\end{array}$ & $\begin{array}{r}10 \cdot 9 \\
10 \cdot 2 \\
7 \cdot 8 \\
7 \cdot 2 \\
9 \cdot 3 \\
8 \cdot 2 \\
8 \cdot 7 \\
11 \cdot 1 \\
7 \cdot 9 \\
4 \cdot 5 \\
10 \cdot 2 \\
8 \cdot 1 \\
8 \cdot 9 \\
7 \cdot 8 \\
9 \cdot 8 \\
7 \cdot 6 \\
8 \cdot 6 \\
7 \cdot 4 \\
7 \cdot 8 \\
7 \cdot 2 \\
8 \cdot 3 \\
8 \cdot 5 \\
8 \cdot 2 \\
7 \cdot 3 \\
9 \cdot 0\end{array}$ & $\begin{array}{l}2 \cdot 789 \\
2 \cdot 945 \\
2 \cdot 226 \\
2 \cdot 721 \\
2 \cdot 538 \\
2 \cdot 661 \\
2 \cdot 603 \\
3 \cdot 284 \\
2 \cdot 861 \\
2 \cdot 680 \\
2 \cdot 232 \\
2 \cdot 536 \\
2 \cdot 688 \\
2 \cdot 547 \\
3 \cdot 009 \\
2 \cdot 375 \\
2 \cdot 675 \\
3 \cdot 239 \\
3 \cdot 385 \\
1 \cdot 614 \\
1.972 \\
2 \cdot 405 \\
2 \cdot 650 \\
2 \cdot 258 \\
2 \cdot 538\end{array}$ & $\begin{array}{r}3 \cdot 8 \\
1 \cdot 6 \\
1 \cdot 0 \\
6 \cdot 7 \\
0 \cdot 9 \\
5 \cdot 8 \\
6 \cdot 2 \\
2 \cdot 2 \\
6 \cdot 7 \\
7 \cdot 5 \\
8 \cdot 7 \\
6 \cdot 4 \\
11 \cdot 8 \\
2 \cdot 3 \\
4 \cdot 8 \\
7 \cdot 6 \\
10 \cdot 8 \\
9 \cdot 1 \\
8 \cdot 4 \\
6 \cdot 5 \\
4 \cdot 6 \\
5 \cdot 6 \\
2 \cdot 6 \\
2 \cdot 0 \\
9 \cdot 2\end{array}$ \\
\hline
\end{tabular}


arthritis responsive to colchicine) and a history of hyperuricaemia (7.4 mg. per cent.) 2 years earlier.

Because of the lower GFR in the hyperuricaemic individuals, urate/creatinine ratios $\times 100$ are reported rather than urate clearances. While the urate/creatinine clearance ratio is lower in the hyperuricaemic group $(5 \cdot 7 \pm 3 \cdot 2$ compared with $6 \cdot 6 \pm 2 \cdot 0)$, it is not significantly so $(0 \cdot 3>\mathrm{P}>$ $0 \cdot 2)$.

The total serum amino acid levels (where "total" equals the sum of aspartic acid, threonine, serine, glutamic acid, glycine, alanine, valine, isoleucine, leucine, tyrosine, phenylalanine, ornithine, lysine and histidine) show the mean in the hyperuricaemic group $(2 \cdot 617 \pm 0.397)$ to be significantly greater than in the control group $(2 \cdot 179 \pm 0 \cdot 313)(P<$ 0.001 ) in confirmation of a previous report (Kaplan and others, 1965). In addition, the mean value of each amino acid is greater in the hyperuricaemic subjects.

In order to determine whether the raised serum levels of amino acids could be accounted for on the basis of renal retention, renal clearances for individual amino acids were calculated, as were amino acid/creatinine clearance ratios. Table III records the range of values obtained for three amino acids: glycine, a purine precursor; valine, a neutral amino acid unrelated to purine metabolism; arginine, a basic amino acid. It is clear that the hyperuricaemic subjects have a decreased clearance of both glycine and valine. Arginine clearance is the same for both groups.

Glutamic acid, glycine, valine, tyrosine, phenylalanine, and histidine all show significantly reduced clearance by the kidneys of hyperuricaemic individuals (Table IV). If the amino acids are separated

TABLE III

RATIOS OF AMINO ACID/CREATININE CLEARANCE $\times 100$

$P$ determined by Student's " $t$ " test

\begin{tabular}{|c|c|c|c|c|c|c|}
\hline \multicolumn{3}{|c|}{ Glycine } & \multicolumn{2}{|c|}{ Valine } & \multicolumn{2}{|c|}{ Arginine } \\
\hline No & ouricaemic & Hyperuricaemic & Normouricaemic & Hyperuricaemic & Normouricaemic & Hyperuricaemic \\
\hline & $\begin{array}{l}0.4 \\
0.4 \\
1.0 \\
1 \cdot 2 \\
1.4 \\
1 \cdot 5 \\
1 \cdot 5 \\
1 \cdot 5 \\
1 \cdot 7 \\
1 \cdot 8 \\
1.9 \\
2.4 \\
2.5 \\
2.6 \\
2.7 \\
3.0 \\
3.2 \\
5.1 \\
6.8 \\
7.6\end{array}$ & $\begin{array}{l}0.4 \\
0.7 \\
0.8 \\
0.8 \\
0.8 \\
0.8 \\
0.8 \\
0.9 \\
0.9 \\
1.2 \\
1.2 \\
1.3 \\
1.4 \\
1.5 \\
1.5 \\
1.8 \\
2.0 \\
2.1 \\
2.9\end{array}$ & $\begin{array}{l}0 \cdot 02 \\
0 \cdot 03 \\
0 \cdot 03 \\
0 \cdot 08 \\
0 \cdot 08 \\
0 \cdot 10 \\
0 \cdot 11 \\
0 \cdot 11 \\
0 \cdot 11 \\
0 \cdot 11 \\
0 \cdot 12 \\
0 \cdot 12 \\
0 \cdot 13 \\
0 \cdot 14 \\
0 \cdot 16 \\
0 \cdot 19 \\
0 \cdot 23 \\
0 \cdot 23 \\
0 \cdot 26 \\
0 \cdot 31\end{array}$ & $\begin{array}{l}0.02 \\
0.04 \\
0.04 \\
0.04 \\
0.04 \\
0.06 \\
0 \cdot 06 \\
0 \cdot 07 \\
0 \cdot 08 \\
0 \cdot 08 \\
0 \cdot 08 \\
0 \cdot 08 \\
0 \cdot 08 \\
0 \cdot 09 \\
0 \cdot 11 \\
0 \cdot 12 \\
0 \cdot 12 \\
0 \cdot 13\end{array}$ & $\begin{array}{l}0 \cdot 00 \\
0 \cdot 07 \\
0 \cdot 08 \\
0 \cdot 09 \\
0 \cdot 09 \\
0 \cdot 13 \\
0 \cdot 14 \\
0 \cdot 16 \\
0 \cdot 17 \\
0 \cdot 18 \\
0 \cdot 21\end{array}$ & $\begin{array}{l}0 \cdot 06 \\
0 \cdot 06 \\
0 \cdot 06 \\
0 \cdot 10 \\
0 \cdot 12 \\
0 \cdot 13 \\
0 \cdot 14 \\
0 \cdot 15 \\
0 \cdot 15 \\
0 \cdot 21 \\
0 \cdot 22 \\
0 \cdot 23 \\
0 \cdot 29\end{array}$ \\
\hline Mean & $2 \cdot 5$ & $1 \cdot 3$ & $0 \cdot 13$ & 0.07 & $0 \cdot 12$ & $0 \cdot 15$ \\
\hline \multicolumn{3}{|c|}{$P<0.01$} & \multicolumn{2}{|c|}{$P<0.005$} & \multicolumn{2}{|c|}{$P>0.05$} \\
\hline
\end{tabular}

TABLE IV

RATIO OF AMINO ACID/CREATININE CLEARANCES $\times 100$ $P$ determined by Student's " $t$ " test

\begin{tabular}{|c|c|c|c|c|c|c|c|c|c|}
\hline \multirow{2}{*}{\multicolumn{7}{|c|}{ Amino Acids }} & \multicolumn{2}{|c|}{ Subject } & \multirow{3}{*}{$\begin{array}{c}\text { Probability } \\
\mathbf{P}<0.25 \\
\mathbf{P}<0.02\end{array}$} \\
\hline & & & & & & & \multirow{2}{*}{$\begin{array}{c}\text { Normouricaemic } \\
\begin{array}{c}0.82 \\
0.15\end{array} \\
\end{array}$} & \multirow{2}{*}{$\begin{array}{c}\text { Hyperuricaemic } \\
1.06 \\
0.08\end{array}$} & \\
\hline Acidic & $\begin{array}{l}\text { Aspartic Acid } \\
\text { Glutamic Acid }\end{array}$ & $\begin{array}{l}. \\
\cdots\end{array}$ & $\begin{array}{l}. \\
\therefore\end{array}$ & $\begin{array}{l}\cdots \\
\cdots\end{array}$ & $\begin{array}{l}. \\
\therefore\end{array}$ & $\begin{array}{l}. \\
\therefore\end{array}$ & & & \\
\hline Neutral & $\begin{array}{ll}\text { Glycine } & . . \\
\text { Alanine } & \ldots \\
\text { Valine } & \ldots \\
\text { Leucine } & \ldots \\
\text { Tyrosine } & \ldots \\
\text { Phenylalanine } \\
\text { Histidine } \quad . .\end{array}$ & $\begin{array}{l}\cdots \\
\cdots \\
\cdots \\
\cdots \\
\cdots \\
\cdots\end{array}$ & $\begin{array}{l}\cdots \\
\cdots \\
\cdots \\
\cdots \\
\cdots\end{array}$ & $\begin{array}{l}\cdots \\
\cdots \\
\cdots \\
\cdots \\
\cdots \\
\cdots \\
\cdots\end{array}$ & $\begin{array}{l}\ldots \\
\cdots \\
\cdots \\
\cdots \\
\cdots \\
\cdots\end{array}$ & $\begin{array}{l}\ldots \\
\cdots \\
\cdots \\
\cdots \\
\cdots \\
\cdots\end{array}$ & $\begin{array}{l}2.46 \\
0.34 \\
0.13 \\
0.16 \\
0.92 \\
0.56 \\
5 \cdot 10\end{array}$ & $\begin{array}{l}1 \cdot 25 \\
0 \cdot 30 \\
0 \cdot 07 \\
0 \cdot 12 \\
0 \cdot 73 \\
0 \cdot 46 \\
2 \cdot 40\end{array}$ & $\begin{array}{l}\mathrm{P}<0.01 \\
\mathbf{P}<0.30 \\
\mathrm{P}<0.01 \\
\mathrm{P}<0.45 \\
\mathrm{P}<0.05 \\
\mathrm{P}<0.05 \\
\mathrm{P}<0.01\end{array}$ \\
\hline Basic & $\begin{array}{ll}\text { Ornithine } & \ldots \\
\text { Lysine } & \ldots \\
\text { Arginine } & \ldots\end{array}$ & $\begin{array}{l}\cdots \\
\cdots \\
\cdots\end{array}$ & $\begin{array}{l}\ldots \\
\cdots \\
\cdots\end{array}$ & $\begin{array}{l}\cdots \\
\cdots \\
\cdots\end{array}$ & $\begin{array}{l}\cdots \\
\cdots \\
\cdots\end{array}$ & $\begin{array}{l}\ldots \\
\cdots \\
\cdots\end{array}$ & $\begin{array}{l}0.43 \\
0.11 \\
0.12\end{array}$ & $\begin{array}{l}0 \cdot 37 \\
0 \cdot 16 \\
0 \cdot 15\end{array}$ & $\begin{array}{l}\mathbf{P}<0.50 \\
\mathbf{P}<0.15 \\
\mathbf{P}<0.35\end{array}$ \\
\hline
\end{tabular}


into acidic, neutral, and basic on the supposition that each of these groups has its own renal transport mechanism (Christensen, Akedo, Oxender, and Winter, 1962), only the neutral amino acids show consistently reduced clearances in hyperuricaemic subjects. (It may or may not be valid to include glycine as a "neutral" amino acid (Scriver, Efron, and Schafer, 1964)).

In order to test the hypothesis that the kidney of the hyperuricaemic patient has a relative inability to excrete some amino acids and not others, studies with exogenous amino acid loading were performed. Fourteen normouricaemic and fourteen hyperuricaemic subjects received $5 \mathrm{~g}$. glycine orally, either alone or in combination with other amino acids as noted above. Similarly, eight subjects in each group received $5 \mathrm{~g}$. valine orally, either alone or in combination, and six normouricaemic and seven hyperuricaemic subjects received $5 \mathrm{~g}$. arginine orally either alone or in combination. Table $\mathrm{V}$ demonstrates that, when the excretion of both glycine and valine is compared before and after the amino acid load, normouricaemic subjects increase their excretion of these two amino acids more than hyperuricaemic subjects. In the 2 hours after the glycine load, normouricaemic subjects excreted a mean of $692 \mu \mathrm{M}$ more glycine than in the two-hour period prior to the load. Hyperuricaemic subjects increased their excretion by only $137 \mu \mathrm{M}$. Similarly, normouricaemic subjects were capable of increasing their valine excretion after a valine load by $9.7 \mu \mathrm{M}$; the hyperuricaemic subjects had a mean increment of only $3 \cdot 8 \mu \mathrm{M}$. There was no significant difference for arginine; this is consistent with the observation that the renal clearance for arginine is the same for normouricaemic and hyperuricaemic subjects.
The differences in renal excretion for glycine and valine could not be accounted for by differences in gastrointestinal absorption as measured by the peak serum level reached, by the time at which the peak was reached, or by the rate of disappearance of the amino acid from the bloodstream. There were no significant differences between the two groups for any of these parameters. The Figure (overleaf) shows examples of the curve of serum concentration against time after the load for glycine and valine in four subjects.

Even though the normal subjects excreted a greater proportion of the administered amino acid, one would not expect any obvious difference in the rate of disappearance of the amino acid from the serum. Only about 1 per cent. of the administered glycine was excreted in the urine during the 2-hour study period, and less of the valine.

To rule out the possibility that the observed differences in renal handling of some amino acids was secondary in some way to high levels of uric acid in the hyperuricaemic group, two normal subjects and one hyperuricaemic subject were subjected to "glycine-valine-arginine tolerance tests" before and after a 2-day feeding of $4 \mathrm{~g}$./day RNA. The data in Table VI (overleaf) indicate that increasing the serum uric acid concentration did not produce a decrease in the glycine or valine excretion after the oral load of amino acids. Endogenous amino acid clearances were similarly unchanged after ingestion of RNA.

In thirteen subjects (five normal subjects and eight hyperuricaemic subjects) uric acid clearance was measured both in the 2-hour control period and in the 2-hour post-amino acid feeding period (nine received glycine alone and four received glycine,

TABLE V

INCREMENT IN AMINO ACID EXCRETION ( $\mu$ M) AFTER AMINO ACID LOADING $P$ determined by Student's " $t$ " test

\begin{tabular}{|c|c|c|c|c|c|}
\hline \multicolumn{2}{|c|}{ Glycine } & \multicolumn{2}{|c|}{ Valine } & \multicolumn{2}{|c|}{ Arginine } \\
\hline Normouricaemic & Hyperuricaemic & Normouricaemic & Hyperuricaemic & Normouricaemic & Hyperuricaemic \\
\hline $\begin{array}{r}87 \\
151 \\
199 \\
305 \\
321 \\
379 \\
580 \\
638 \\
951 \\
997 \\
1063 \\
1597 \\
1711\end{array}$ & $\begin{array}{r}24 \\
51 \\
60 \\
69 \\
73 \\
76 \\
78 \\
142 \\
144 \\
153 \\
225 \\
243 \\
449\end{array}$ & $\begin{array}{r}4 \cdot 7 \\
5 \cdot 6 \\
6 \cdot 4 \\
6 \cdot 9 \\
8 \cdot 5 \\
10 \cdot 1 \\
13 \cdot 3 \\
21 \cdot 9\end{array}$ & $\begin{array}{r}0 \cdot 0 \\
1 \cdot 1 \\
2 \cdot 2 \\
2 \cdot 3 \\
2 \cdot 4 \\
3 \cdot 6 \\
4 \cdot 1 \\
14 \cdot 5\end{array}$ & $\begin{array}{l}0 \cdot 0 \\
0 \cdot 4 \\
0 \cdot 6 \\
2 \cdot 1 \\
5 \cdot 2 \\
6 \cdot 4\end{array}$ & $\begin{array}{l}0 \cdot 0 \\
0 \cdot 0 \\
0 \cdot 4 \\
1 \cdot 0 \\
3 \cdot 0 \\
3 \cdot 2 \\
3 \cdot 5\end{array}$ \\
\hline Mean & 137 & $9 \cdot 7$ & $3 \cdot 8$ & $2 \cdot 5$ & $1 \cdot 6$ \\
\hline \multicolumn{2}{|c|}{$P<0.01$} & \multicolumn{2}{|c|}{$P<0.01$} & \multicolumn{2}{|c|}{$P>0.2$} \\
\hline
\end{tabular}

The increment equals the number of micromoles of the amino acid excreted in the 2-hour period following the ingestion of $5 \mathrm{~g}$. of the amino less the amount of the amino acid excreted in tne 2-hour period before ingestion. 

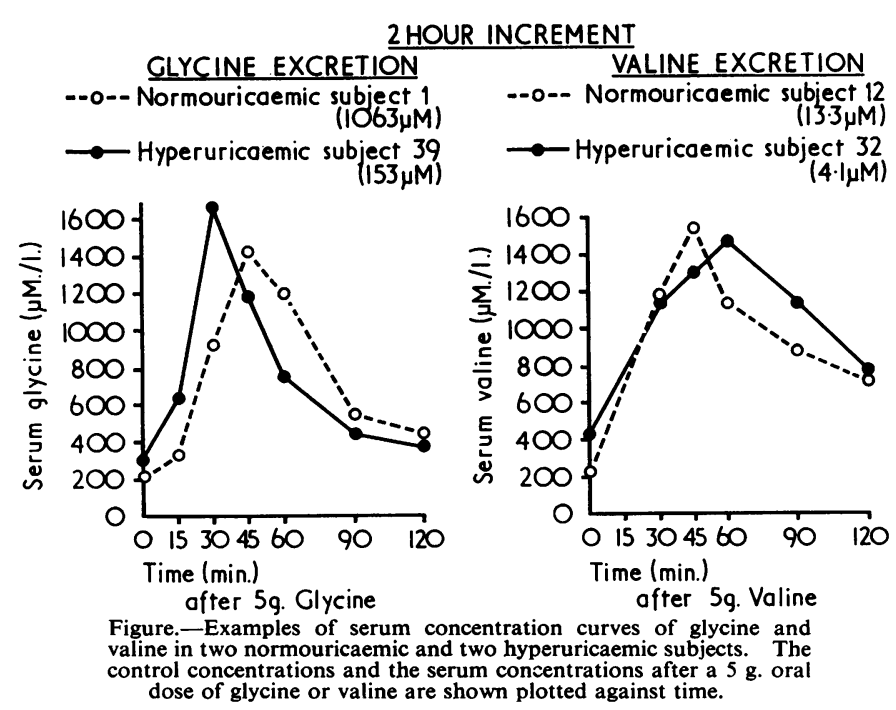

TABLE VI

EFFECT OF RNA INGESTION ON EXCRETION OF GLYCINE AND VALINE AFTER A 5 g. ORAL DOSE

\begin{tabular}{|c|c|c|c|c|c|c|c|}
\hline \multirow[t]{2}{*}{$\begin{array}{l}\text { Subject } \\
\text { No. }\end{array}$} & \multicolumn{2}{|c|}{$\begin{array}{l}\text { Serum Uric Acid } \\
\text { (mg. per cent.) }\end{array}$} & \multicolumn{2}{|c|}{$\begin{array}{c}\text { Glycine Increment } \\
(\mu \mathrm{M})\end{array}$} & \multicolumn{3}{|c|}{$\begin{array}{c}\text { Valine Increment } \\
(\mu \mathrm{M})\end{array}$} \\
\hline & Before & After & Before & After & Before & After & \\
\hline $\begin{array}{l}25 \\
21 \\
50\end{array}$ & $\begin{array}{l}4 \cdot 4 \\
5 \cdot 4 \\
7 \cdot 3\end{array}$ & $\begin{array}{r}6 \cdot 5 \\
7 \cdot 1 \\
11 \cdot 2\end{array}$ & $\begin{array}{r}199 \\
321 \\
73\end{array}$ & $\begin{array}{r}234 \\
364 \\
66\end{array}$ & $\begin{array}{l}6 \cdot 4 \\
4 \cdot 7 \\
1 \cdot 1\end{array}$ & $\begin{array}{l}6 \cdot 2 \\
4 \cdot 8 \\
6 \cdot 6\end{array}$ & 음 \\
\hline
\end{tabular}

The increment is the excretion in micromoles of the amino acid after the amino acid load less the excretion before the load, as in Table $\vec{\nabla}$.

valine, and arginine). The mean uric acid clearance in these thirteen subjects before receiving oral amino acid was $6.3 \mathrm{ml}$./min., but after the amino acid feeding, the mean uric acid clearance was $9.7 \mathrm{ml} . / \mathrm{min}$. The mean difference was thus 3.4 $\mathrm{ml} . / \mathrm{min}$. (S.E. $= \pm 1 \cdot 4$ ) giving a $P$ value of less than 0.05 (" $t$ " $=2.5$ using the Fisher Test). This increase in renal clearance of uric acid is matched by a fall in the mean serum uric acid value over the 2-hour period from 7.2 to $6.7 \mathrm{mg}$. per cent. The mean difference of $0.5 \mathrm{mg}$. per cent. gave a $P$ value of less than 0.01 (" $t$ " $=3 \cdot 3$ by the Fisher test).

\section{Discussion}

Hyperuricaemia is of heterogeneous origin. There is good evidence for polygenic inheritance for this trait (Hauge and Harvald, 1955). Recent studies have shown that one form of familial hyperuricaemia and gout, characterized by marked overproduction of uric acid, is due to a partial deficiency of the enzyme, hypoxanthine-guanine phosphoribosyl transferase (Kelley, Rosenbloom, Henderson, and Seegmiller, 1967). Environmental factors also play a role. Hyperuricaemia is related

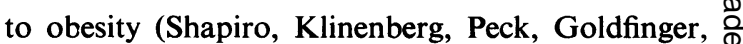
and Seegmiller, 1964; Křížek, 1966), to diet (Shapiro and others, 1964), and to drugs (Sorensen, 1962), among other factors.

The precise relationship between hyperaminoacidaemia and hyperuricaemia is not clear. In the work reported here, there was some degree of overlap in the serum amino acid levels of the controls and those with hyperuricaemia, but the mean level in the hyperuricaemic subjects was significantly higher $(\mathrm{P}<0.001)$. In addition, renal clearances of the neutral amino acids were consistently lower in the hyperuricaemic subjects. Renal handling of exogenously administered glycine and valine similar- $\frac{T}{O}$ ly differed in the two groups; the hyperuricaemic subjects were unable to excrete as much of the two o amino acids as did the controls. These differences $\mathrm{N}$ in renal handling of amino acids were clearly not $N$ the result of hyperuricaemia per se, because they were not influenced by ingestion of RNA, inducing rises in serum urate levels.

It has been suggested by Wyngaarden (1966) that $\mathscr{D}$ there may be a defect in the kidney of the hyperuri- ? caemic subject which causes decreased secretion of $\frac{T}{T}$ uric acid at the tubular cell. The data presented 
here suggest that such a hypothetical defect in some patients with hyperuricaemia may actually involve a group of substances, including the neutral amino acids, rather than just uric acid alone.

It is not surprising that there is a concordant relationship in the renal handling of uric acid and amino acids. The most pertinent data relating to this point are that glycine and protein feeding in humans produces uricosuria (Christman and Mosier, 1929; Leopold, Bernhard, and Jabobs, 1925; Folin, Berglund, and Derick, 1924). This is confirmed by the present studies demonstrating an increased uric acid clearance after amino acid ingestion, accompanied by a fall in the serum uric acid concentration.

Such evidence suggests that uric acid and some amino acids compete for reabsorption by the renal tubule. While there is no direct evidence that amino acids are secreted by the kidney, competition between uric acid and other weak organic acids is well described in other syndromes (e.g. hyperbetahydroxybuturicacidaemia (Scott, McCallum, and Holloway, 1964; Goldfinger, Klinenberg, and Seegmiller, 1965), starvation (Pabico, Canfield, and Barry, 1965), and von Gierke's disease (Howell, Ashton, and Wyngaarden, 1962. It may be that tubular transport of amino acids is affected by the same renal abnormality leading to decreased uric acid excretion in some hyperuricaemic subjects.

\section{Summary}

This study has demonstrated that the clearance of several amino acids by the kidneys of hyperuricaemic subjects is diminished. Hyperuricaemia alone does not appear to be the cause of the altered amino acid clearance. It is suggested that the renal tubular cells in hyperuricaemic persons have a defect in transport mechanisms leading to a reduction in secretion of both uric acid and certain amino acids.

\section{REFERENCES}

Bonsnes, R. W., and Taussky, H. H. (1945). J. biol. Chem., 158, 581 (On the colorimetric determination of creatinine by the Jaffe reaction).

Christensen, N. H., Akedo, H., Oxender, D. L., and Winter, C. G. (1962). "On the Mechanism of Amino Acid Transport into Cells", in "Amino Acid Pools: Proc. Symposium on Free Amino Acids, Duarte, California, 1961”, ed. J. T. Holden, pp. 527-538. Elsevier, Amsterdam.

Christman, A. A., and Mosier, E. C. (1929). J. biol. Chem., 83, 11 (Purine metabolism. II. The. effect of the ingestion of glycine on the excretion of endogenous uric acid).

Dickinson, J. C., Rosenblum, M., and Hamilton, P. B. (1965). Pediatrics, 36, 2 (Ion exchange. chromatography of the free amino acids in the plasma of the newborn infant).

Folin, O., Berglund, H., and Derick, C. (1924). J. biol. Chem., 60, 361 (The uric acid problem).

Goldfinger, S., Klinenberg, J. R., and Seegmiller, J. E. (1965). New Engl. J. Med., 272, 351 (Renal retention of uric acid induced by infusion of beta-hydroxybutyrate and acetoacetate).

Harrison, H. E. (1942). Proc. Soc. exp. Biol. (N.Y.), 49, 111 (A modification of the diphenylamine method for determination of inulin).

Hauge, M., and Harvald, B. (1955). Acta med. scand., 152, 247 (Heredity in gout and hyperuricemia).

Howell, R. R., Ashton, D. M., and Wyngaarden, J. B. (1962). Pediatrics, 29, 553 (Glucose-6phosphatase deficiency glycogen storage disease).

Kaplan, D., Bernstein, D., Wallace, S. L., and Halberstam, D. (1965). Ann. intern. Med., 62, 658 (Serum and urinary amino acids in normouricemic and hyperuricemic subjects).

—, Wallace, S. L., and Halberstam, D. (1966). Nature (Lond.), 209, 213 (Renal handling of glycine in primary hyperuricaemia).

Kelley, W. N., Rosenbloom, F. M., Henderson, J. F., and Seegmiller, J. E. (1967). J. clin. Invest., 46, 1078 (Specific enzyme defect associated with purine overproduction in adult gout).

Křížek, V. (1966). Ann. rheum. Dis., 25, 456 (Serum uric acid in relation to body weight).

Leopold, J. S., Bernhard, A., and Jacobi, H. G. (1925). Amer. J. Dis. Child., 29, 191 (Uric acid metabolism of children).

Nugent, C. A., and Tyler, F. H. (1959). J. clin. Invest., 38, 1890 (The renal excretion of uric acid in patients with gout and in nongouty subjects).

Pabico, R. C., Canfield, C. J., and Barry, K. G., (1965). Clin. Res., 13, 45 (The effects of acute total caloric starvation on uric acid metabolism in obese human subjects).

Praetorius, E. (1949). Scand. J. clin. Lab. Invest., 1, 222 (An enzymatic method for the determination of uric acid by ultraviolet spectrophotometry).

Scott, J. T., McCallum, F. M., and Holloway, V. P. (1964). Clin. Sci., 27, 209 (Starvation, ketosis, and uric acid excretion).

Scriver, C. R., Efron, M. L., and Schafer, I. A. (1964). J. clin. Invest., 43, 374 (Renal tubular transport of proline, hydroxyproline, and glycine in health and in familial hyperprolinemia). 
Seegmiller, J. E., Grayzel, A. I., Howell, R. R., and Plato, C. (1962). Ibid., 41, 1094 (The renal excretion of uric acid in gout).

Shapiro, J. R., Klinenberg, J. R., Peck, W., Goldfinger, S. E., and Seegmiller, J. E. (1964). Arthr. and Rheum., 7, 343 (Hyperuricemia associated with obesity and intensified by caloric restriction).

Sorensen, L. B. (1962). Arch. intern. Med., 109, 379 (The pathogenesis of gout).

Wyngaarden, J. G. (1966). "Etiology and Pathogenesis of Gout", in "Arthritis", ed. J. L. Hollander, 7th ed., pp. 890-922. Lea and Febiger, Philadelphia.

\section{L'excrétion des acides aminés dans l'hypéruricémie primaire}

\section{RÉSUMÉ}

Cette étude a démontré que l'élimination de plusieurs acides aminés par les reins de sujets atteints d'hyperuricémie est diminué. L'hyperuricémie seule ne semble pas être la cause de l'élimination des acides aminés altérés. Il est suggéré que les cellules des tubes urinifères chez les personnes atteintes de l'hyperuricémie ont un défaut dans l'appareil d'élimination conduisant à une réduction de la sécretion de l'acide urique ainsi que celle de certains acides aminés.
Excreción de aminoácido en la hiperuricemia primaria

\section{SUMARIO}

Este estudio ha demostrado que la eliminación de varios aminoácidos por los riñones de sujetos con hiperuricemia es reducida. La hiperuricemia, por sí sola, no parece ser la causa de la alterada eliminación de aminoácido. Se sugiere que las células tubulares renales en personas hiperuricémicas tienen un defecto en los mecanismos de transporte, que conducen a una disminución en la secreción tanto de ácido úrico como de ciertos aminoácidos. 